Research Article

\title{
Gene variation and genetic differentiation among populations of the solitary mud dauber wasp Trypoxylon (Trypargilum) albitarse Fabricius 1804 (Hymenoptera, Crabronidae)
}

\author{
Antonio C.B. Bergamaschi ${ }^{1}$ and Marco A. Del Lama ${ }^{2}$ \\ ${ }^{1}$ Departamento de Biologia, Universidade Estadual do Centro-Oeste, Guarapuava, PR, Brazil. \\ ${ }^{2}$ Departamento de Genética e Evolução, Universidade Federal de São Carlos, São Carlos, SP, Brazil.
}

\begin{abstract}
Trypoxylon is a genus of solitary crabronid wasps whose population genetics is poorly known. The purpose of the present study was to investigate the genetic variation and differentiation among five populations of Trypoxylon albitarse, a species widely distributed throughout the Neotropics, with records from Panama to northern Argentina. Eight species-specific microsatellite loci were used for genotyping 96 adult wasps (one female per nest) sampled at five sites in Brazil. The analysis of allelic richness and private alleles indicated high genetic diversity in the populations sampled. Pairwise comparisons using the $F_{s t}$ and $D_{\text {est }}$ indices revealed significant differentiation for all, but one pair of populations. $F_{s t}, D_{e s t}$, AMOVA and assignment test values pointed to inter-population differentiation. Additionally, the analysis of population structure using Bayesian and PCA methods characterized two alternative genetic groups. The Mantel test indicated no correlation between genetic and geographic distances. Despite evidence of considerable dispersal capacity for $T$. albitarse, the data indicate low to moderate population structuring in this species.
\end{abstract}

Keywords: population genetics, wasps, Crabronidae, SSR markers.

Received: April 19, 2015; Accepted: July 20, 2015.

\section{Introduction}

Among aculeate members of the order Hymenoptera, the family Crabronidae is a group of wasps that stands out for its worldwide distribution as well as for exhibiting a wide variety of nesting and foraging strategies. About 9,000 species have been described (Pulawski, 2014) and most do not exhibit social organization (Melo, 2000; O'Neill, 2001). Although some morphological studies have suggested that Crabronidae could form a monophyletic group, considered by some to be a sister group of Apidae (Lomholdt, 1982; Prentice, 1998; Melo, 1999; Michener, 2007), studies involving morphological (Alexander, 1992) and molecular data (Lohrmann, et al., 2008; Debevec et al., 2012) suggest that Crabronidae may not be a monophyletic clade and that bees may have arisen within this group. Despite having an important position in the Apoidea phylogeny, genetic studies involving crabronid wasps are scarce.

Trypoxylon is the most diverse genus of the family Crabronidae, with about 634 described species, which have a worldwide geographical distribution (Pulawski, 2014).

Send correspondence to Antonio Carlos Bragato Bergamaschi. Departamento de Biologia, Centro de Desenvolvimento Tecnológico e Educacional de Guarapuava, Universidade Estadual do Centro-Oeste, Rua Simeão Varela de Sá 3, 85040-080 Guarapuava, PR, Brazil. E-mail: acbbergamaschi@gmail.com.
Aspects of the natural history of these solitary hunter spider wasps are well known. However, the literature offers few reports addressing the population genetics of species of this genus or the other crabronid wasps using genetic markers. Until now, only allozyme markers were used to study the population genetics of Trypoxylon species; firstly, Trypoxylon albitarse and Trypoxylon rogenhoferi populations were studied by Peruquetti (2003) and thereafter, Trypoxylon aurifrons, Trypoxylon nitidum and Trypoxylon lactitarse populations by Santoni (2008). Despite the low level of heterozygosity of the markers employed, both authors found significant genetic differentiation among populations of these five species and suggested that this result would be due to a possible philopatry behavior of these wasps.

The solitary mud dauber Trypoxylon albitarse (Hymenoptera, Crabronidae) is widely distributed throughout the Neotropics, with records from Panama to northern Argentina, and is easily found on the walls of human constructions, such as buildings and bridges, especially if located near forested areas (Amarante, 1991, 2002). Based on the low recapture rates of marked specimens during a behavioral study, Amarante (1991) proposed that this species has a considerable high dispersal capacity. The wide geographical distribution of the spe- 
cies, the presumed high dispersal capacity and the successful nesting behavior in areas under anthropic pressure provide evidence of a lack of strong barriers to gene flow among populations of T. albitarse. However, the population genetic structure reported for the species (Peruquetti, 2003) and others of the same genus (Santoni, 2008) raises questions regarding the degree of dispersal among males and the effect of the presumed philopatric behavior of females (Melo, 2000) on the population genetic structure of species of Trypoxylon. Thus, the purpose of the present study was to estimate the degree of genetic differentiation among populations of $T$. albitarse using eight speciesspecific microsatellite loci.

\section{Material and Methods}

\section{Sampling and fieldwork}

Specimens of $T$. albitarse were collected from five populations in Brazil: Ilhéus (state of Bahia), Viçosa (state of Minas Gerais), Lavras (state of Minas Gerais), São Carlos (state of São Paulo) and Guarapuava (state of Paraná) (Figure 1 and Table 1). The sampling sites were located in the northeastern, southeastern and southern regions of the country, with distances ranging from $238 \mathrm{~km}$ (Lavras to Viçosa) to $1797 \mathrm{~km}$ (Guarapuava to Ilhéus) between sites.

Trypoxylon albitarse nests with mud tubes found on the walls of human constructions were carefully opened with fine-tipped tweezers. When immature individuals in the pupal stage were found, the cocoons were placed in individual, duly labeled, plastic tubes, taken to the laboratory and kept at room temperature until the emergence of the adult stage, when the sex was determined, followed by storage of the material at $-20{ }^{\circ} \mathrm{C}$ for subsequent DNA extraction.

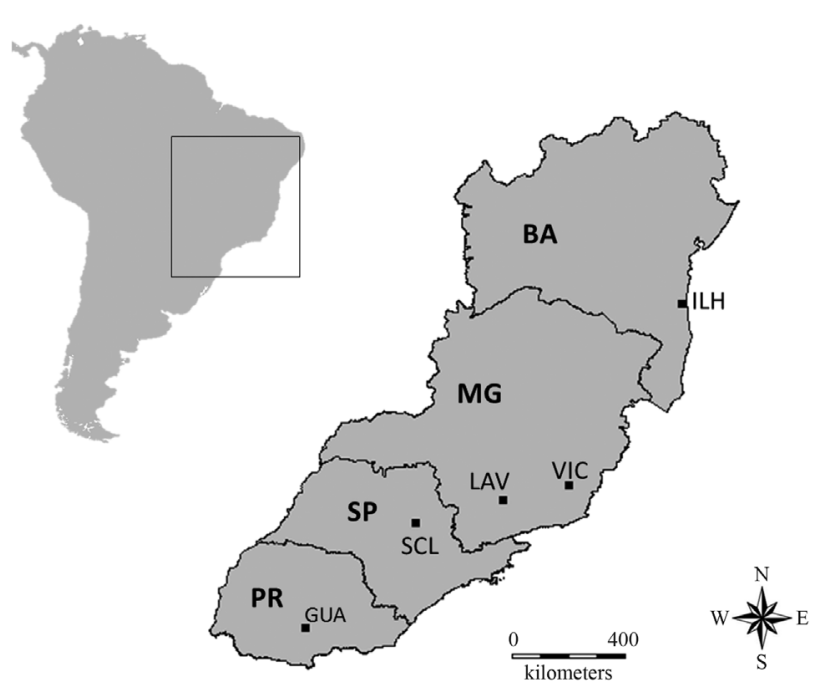

Figure 1 - Map illustrating the geographical origin of five samples of Trypoxylon albitarse analyzed. The site codes were described in Table 1.

\section{DNA extraction, microsatellite loci amplification and genotyping}

Total DNA was extracted after the maceration of three pairs of legs or the mesosoma of adult specimens of $T$. albitarse using protocols based on either phenol-chloroform (Fernandes-Salomão et al., 2005) or Chelex 100 (Walsh et al., 1991). Samples were genotyped for nine species-specific microsatellite loci: TALB01, TALB02, TALB03, TALB05, TALB06, TALB07, TALB09, TALB12 and TALB14 (Almeida et al., 2013.). Polymerase chain reactions (PCR) were performed in an Eppendorf Mastercycler thermal cycler (Hamburg, Germany) using $250 \mu \mathrm{M}$ of each dNTP, $2.5 \mathrm{mM}$ of $\mathrm{MgCl}_{2}, 0.5 \mu \mathrm{M}$ of the fluorescently labeled forward primer, $0.5 \mathrm{mM}$ of the reverse primer, 1x BioTools buffer and $1 \mathrm{U}$ of Taq DNA polymerase (BioTools, Madrid, Spain) in a final volume of $10 \mu \mathrm{L}$. Amplification consisted of an initial denaturation step at $94{ }^{\circ} \mathrm{C}$ for $3 \mathrm{~min}$, followed by 35 cycles of denaturation at $94{ }^{\circ} \mathrm{C}$ for $30 \mathrm{~s}$, annealing of the primers at the specific temperature for each locus indicated by Almeida et al. (2013) for $20 \mathrm{~s}$ and chain extension at $72{ }^{\circ} \mathrm{C}$ for $1 \mathrm{~min}$. Amplification cycles were followed by a final extension step at $70{ }^{\circ} \mathrm{C}$ for $10 \mathrm{~min}$.

Approximately $13 \%$ of the samples were retyped to verify the reproducibility of the data and confirm the genotypes considered when weak or double peaks were found. To minimize the occurrence of missing data, PCR was performed up to three times in cases of the absence of amplification for a given locus.

The amplification products were analyzed after a run in the MegaBace-1000 automated sequencer (GE Healthcare, Buckinghamshire, United Kingdom). Fragment size was established by comparing the peaks in the set of samples to the ET550R size marker in the MegaBace Fragment Profiler program, version 1.2.

\section{Data analysis}

As in most species of Hymenoptera, T. albitarse males develop from unfertilized eggs and are haploid, whereas females develop from fertilized eggs and are diploid. Based on this feature, only females were used in the genetic analysis. To avoid biased results due to the familial structure of the nests, only one female per nest was considered in the final dataset. The number of wasps analyzed per sampling site varied from 12 to 37 (Table 3).

Given the different sample size of each population of T. albitarse analyzed, the HP-Rare program, version1.1 (Kalinowski, 2005), which applies the rarefaction method (Kalinowski, 2004), was used to estimate allele richness and the occurrence of private alleles in each population. Genotype data were analyzed using the Arlequin program, version 3.11 (Excoffier et al., 2005) to obtain estimates of observed and expected heterozygosity for each locus and for the verification of linkage disequilibrium between loci. 
Table 1 - Characterization of the sampling sites of Trypoxylon albitarse nests.

\begin{tabular}{lcl}
\hline Code & \multicolumn{1}{c}{ Sampling site } & Geographic coordinates \\
\hline ILH & Ilhéus (BA), Campus da Universidade Estadual de Santa Cruz (UESC) & $14^{\circ} 47^{\prime} 46^{\prime}$ S, $39^{\circ} 10^{\prime} 28^{\prime}$ W \\
VIC & Viçosa (MG), Campus da Universidade Federal de Viçosa (UFV) & $20^{\circ} 45^{\prime} 14^{\prime} \mathrm{S}^{\circ}, 42^{\circ} 52^{\prime} 53^{\prime}$ ' W \\
LAV & Lavras (MG), Campus da Universidade Federal de Lavras (UFLA) & $21^{\circ} 13^{\prime} 40^{\prime}$ S, $44^{\circ} 57^{\prime} 50^{\prime}$ W \\
SCL & São Carlos (SP), Campus da Universidade Federal de São Carlos (UFSCar) & $21^{\circ} 58^{\prime} 54^{\prime}$ S, $47^{\circ} 52^{\prime} 49^{\prime}$ W \\
GUA & Guarapuava (PR), Parque Municipal das Araucárias & $25^{\circ} 20^{\prime} 44^{\prime}$ S, $51^{\circ} 27^{\prime} 31^{\prime}$ W \\
\hline
\end{tabular}

The significance of differences in genetic diversity between populations was tested using a paired $t$-test of arcsine transformed He values (Archie, 1985). Significant deviations from the Hardy-Weinberg equilibrium were determined using the GenAlEx program, version 6.5 (Peakall and Smouse, 2006). A 5\% significance level $(\mathrm{p}<0.05)$ was adopted for all statistical tests, and the sequential Bonferroni correction (Rice, 1989) was used when significant deviations were detected.

Population differentiation was estimated using total and pairwise $F_{s t}$ (Weir and Cockerham, 1984) and $D_{\text {est }}$ (Jost, 2008) values using the FSTAT 2.9.3.2 (Goudet, 2001) and GenAlEx 6.5 (Peakall and Smouse, 2006) programs, respectively. In order to test the association of pairwise results obtained for both indexes, the Pearsons $r$-correlation coefficient was estimated using the program STATISTICA 7.0 (StatSoft Inc. 2004). Additionally, the partition of genetic variation within and among populations was estimated through Analysis of Molecular Variance (AMOVA) (Excoffier et al., 1992) using the program Arlequin 3.11 (Excoffier et al., 2005). The level of genetic differentiation among populations was also estimated by an assignment test conducted in the GenAlEx program, version 6.5 (Peakall and Smouse, 2006), which indicates the percentage of individuals correctly assigned to their original populations.

Population structure was investigated using a clustering approach with Bayesian inference in the Structure program, version 2.3.4 (Pritchard et al., 2000), for which no $a$ priori information was provided on the origin of individuals. Using the mixed ancestry model with independent allele frequencies among populations, five simulations were conducted for each inferred $K$ (number of genetic clusters), which ranged from 1 to 5 . In each run, 1,000,000 repetitions of burn-in were conducted, followed by 5,000,000 MCMC repetitions. The estimated probabilities for each run were used to estimate $\Delta K$ (Evanno et al., 2005), which represents the most probable number of genetic clusters in the database.

Principal component analysis (PCA) was performed to identify the distribution of genetic variation in the geographic samples using the GenAlEx program (Peakall and Smouse, 2006). This program was also employed to test the correlation between genetic and geographic distances using a Mantel test (Mantel 1967).
The inbreeding coefficient $\left(F_{i s}\right)$ (Weir and Cockerham, 1984) was verified using the program FSTAT 2.9.3.2 (Goudet, 2001). The software BOTTLENECK 1.2.02 (Piry et al., 1999) was used to test the heterozygosity excess and to estimate possible genetic bottlenecks signatures in all populations. As recommended by Piry et al. (1999) for microsatellite data, a two-phase mutation model (TPM) was assumed, with 95\% single-step mutations and 5\% multiple-step mutations, and variance among multiple steps of 12. Subsequently, heterozygosity excess significance over all loci (p) was determined by the Wilcoxon's test.

The Kingroup2 program (Konovalov et al., 2004) was used to determine kinship among females of each population through estimates of maximum likelihood using the approach described by Queller and Goodnight (1989) and Goodnight and Queller (1999).

\section{Results}

\section{Genetic diversity}

Trypoxylon albitarse females $(\mathrm{n}=96)$ from the five sampling sites were genotyped for nine microsatellite loci. As locus TALB12 was monomorphic in all samples, only eight loci were considered in the analysis. The lack of amplification for some loci, even after repetitions of the PCR, generated a missing data rate of nearly $3 \%$.

Table 2 displays the estimates of allelic richness (A) and private alleles (Ap). Table 3 displays data on sample size, estimates of expected $(\mathrm{He})$ and observed (Ho) intralocus and mean heterozygosity as well as significant deviations from the Hardy-Weinberg equilibrium. No linkage disequilibrium was observed between the pairs of loci used in the genetic analyses.

\section{Genetic structure}

Estimates of differentiation using the $F_{s t}$ and $D_{e s t}$ indices for pairs of populations were obtained for all loci. The results indicated significant genetic differentiation between all pairs of populations, but one (Lavras vs. Guarapuava) (Table 4). The Pearson's $r$ correlation coefficient among the pairwise values of both indexes revealed a positive association between them $(r=0.994)$. Overall $F_{s t}$ and $D_{e s t}$ values $[0.11(\mathrm{p}<0.01)$ and $0.13(\mathrm{p}<0.01)$, respectively] indicated significant population differentiation. The distribution of genetic variation within and among populations 
Table 2 - Allelic richness (A) and private alleles (Ap) estimated using rarefaction method at eight microsatellite loci of five populations of Trypoxylon albitarse. The site codes were described in Table 1.

\begin{tabular}{|c|c|c|c|c|c|c|c|c|c|c|}
\hline \multirow[t]{2}{*}{ Locus } & \multicolumn{2}{|c|}{ ILH } & \multicolumn{2}{|c|}{ VIC } & \multicolumn{2}{|c|}{ LAV } & \multicolumn{2}{|c|}{ SCL } & \multicolumn{2}{|c|}{ GUA } \\
\hline & $\mathrm{A}$ & Ap & A & Ap & A & Ap & $\mathrm{A}$ & Ap & $\mathrm{A}$ & Ap \\
\hline$T A L B 01$ & 2.87 & 0.26 & 2.29 & 0.49 & 3.65 & 1.08 & 1.65 & 0.20 & 2.05 & 0.006 \\
\hline TALB02 & 3.60 & 0.37 & 2.10 & 0.19 & 2.26 & 0.36 & 2.77 & 0.69 & 2.56 & 0.58 \\
\hline TALBO3 & 3.15 & 0.01 & 3.42 & 0.10 & 3.09 & 0.01 & 3.34 & 0.09 & 3.40 & 0.51 \\
\hline TALB05 & 3.83 & 0.15 & 5.23 & 0.84 & 3.70 & 0.45 & 4.95 & 1.73 & 4.62 & 0.32 \\
\hline TALB06 & 2.90 & 0.0006 & 3.18 & 1.64 & 3.42 & 0.37 & 3.57 & 0.49 & 3.53 & 0.18 \\
\hline TALB07 & 5.20 & 0.71 & 5.90 & 1.26 & 6.35 & 2.18 & 5.20 & 1.12 & 6.27 & 2.37 \\
\hline TALB09 & 1.00 & 0 & 1.00 & 0 & 1.52 & 0.20 & 1.00 & 0 & 1.96 & 0.64 \\
\hline$T A L B 14$ & 1.65 & 0.23 & 1.88 & 0.56 & 1.00 & 0 & 1.97 & 0.4 & 1.66 & 0.46 \\
\hline
\end{tabular}

Table 3 - Sample size (n), observed (Ho) and expected (He) intralocus heterozygosity and chi-square values for deviations from Hardy-Weinberg Equilibrium (HWE) in five populations of Trypoxylon albitarse from Brazil genotyped at eight microsatellite loci. The site codes were described in Table 1.

\begin{tabular}{|c|c|c|c|c|c|c|c|c|c|c|}
\hline Population & & $T A L B 01$ & TALB02 & TALB03 & TALB05 & TALB06 & TALB07 & TALB09 & TALB14 & Mean \\
\hline \multirow[t]{3}{*}{$\operatorname{ILH}(\mathrm{n}=17)$} & $\mathrm{H}_{\mathrm{o}}$ & 0.41 & 0.31 & 0.58 & 0.29 & 0.25 & 0.64 & - & 0.17 & 0.38 \\
\hline & $\mathrm{H}_{\mathrm{e}}$ & 0.57 & 0.71 & 0.7 & 0.74 & 0.67 & 0.86 & - & 0.16 & 0.63 \\
\hline & HWE & 9.66 & $23.28 *$ & 3.44 & $33.88^{*}$ & $14.45^{*}$ & 86.19 & - & 0.15 & \\
\hline \multirow[t]{3}{*}{$\operatorname{VIC}(n=16)$} & $\mathrm{H}_{\mathrm{o}}$ & 0.12 & 0.43 & 0.87 & 0.57 & 0.42 & 0.73 & - & 0.12 & 0.46 \\
\hline & $\mathrm{H}_{\mathrm{e}}$ & 0.41 & 0.36 & 0.69 & 0.87 & 0.62 & 0.91 & - & 0.23 & 0.58 \\
\hline & HWE & $21.44 *$ & 1.25 & 4.11 & 41.27 & 4.9 & 53.81 & - & 16.08 & \\
\hline \multirow[t]{3}{*}{$\operatorname{LAV}(\mathrm{n}=14)$} & $\mathrm{H}_{\mathrm{o}}$ & 0.14 & 0.28 & 0.61 & 0.57 & 0.58 & 0.78 & 0 & - & 0.42 \\
\hline & $\mathrm{H}_{\mathrm{e}}$ & 0.72 & 0.37 & 0.64 & 0.72 & 0.72 & 0.93 & 0.14 & - & 0.6 \\
\hline & HWE & $33.05^{*}$ & 14.46 & 5.07 & 6.78 & $12.91 *$ & 101.01 & $13^{*}$ & - & \\
\hline \multirow[t]{3}{*}{$\operatorname{SCL}(\mathrm{n}=37)$} & $\mathrm{H}_{\mathrm{o}}$ & 0.13 & 0.51 & 0.56 & 0.86 & 0.64 & 0.89 & - & 0.32 & 0.56 \\
\hline & $\mathrm{H}_{\mathrm{e}}$ & 0.17 & 0.55 & 0.66 & 0.84 & 0.7 & 0.86 & - & 0.28 & 0.58 \\
\hline & HWE & 37.2 & 78.03 & 7.88 & 60.93 & $31.18^{*}$ & 46.44 & - & 1.26 & \\
\hline \multirow[t]{3}{*}{ GUA $(n=12)$} & $\mathrm{H}_{\mathrm{o}}$ & 0.16 & 0.16 & 0.66 & 0.75 & 0.66 & 0.58 & 0.09 & 0.08 & 0.39 \\
\hline & $\mathrm{H}_{\mathrm{e}}$ & 0.3 & 0.47 & 0.65 & 0.84 & 0.73 & 0.92 & 0.25 & 0.16 & 0.54 \\
\hline & HWE & 4.65 & 12.52 & 11 & 12.93 & 8.24 & $93.81 *$ & $11.03 *$ & $24 *$ & \\
\hline
\end{tabular}

- Monomorphic loci.

* Significant deviation from HWE even after sequential Bonferroni correction $(\mathrm{p}<0.05)$.

Table 4 - $F_{s t}$ (below the diagonal) and $D_{\text {est }}$ (above the diagonal) values for pairs of Trypoxylon albitarse populations from five sites in Brazil genotyped at eight microsatellite loci. The site codes were described in Table 1.

\begin{tabular}{lccccc}
\hline & ILH & VIC & LAV & SCL & GUA \\
\hline ILH & - & 0.100 & 0.095 & 0.085 & 0.102 \\
VIC & 0.062 & - & 0.275 & 0.082 & 0.212 \\
LAV & 0.061 & 0.131 & - & 0.231 & $0.013^{*}$ \\
SCL & 0.049 & 0.050 & 0.110 & - & 0.165 \\
GUA & 0.064 & 0.108 & $0.032^{*}$ & 0.085 & - \\
\hline
\end{tabular}

*No significant genetic differentiation $(\mathrm{p}<0.05)$.

was determined using AMOVA (Table 5). The assignment test indicated that $76 \%$ of individuals analyzed were properly assigned to their populations of origin.
The differentiation pattern obtained through Bayesian analysis identified two alternative genetic clusters $(K=2)$ (Figure 2). A similar pattern was found using PCA (Figure 3). Both analyses revealed similar results and indicated that individuals from Ilhéus could be assigned to one or another of the two genetic groups identified in the analysis. The Mantel test indicated no correlation between genetic and geographic distances $(r=-0.47 ; \mathrm{p}=0.1)$.

$F_{i s}$ values over all loci were positive and significantly different from zero in the five populations, ranging from 0.154 to $0.285[0.157(\mathrm{p}<0.01), 0.169(\mathrm{p}<0.01), 0.285$ $(\mathrm{p}<0.01), 0.154(\mathrm{p}<0.05)$ and $0.223(\mathrm{p}<0.01)$ for Ilhéus, Viçosa, Lavras, São Carlos and Guarapuava respectively].

The test carried out in the program BOTTLENECK resulted in significant values, indicating a possible bottleneck effect for all the populations studied. The Wilcoxon 
Table 5 - Distribution of genetic variation within and among Trypoxylon albitarse populations genotyped at eight microsatellite loci according to AMOVA.

\begin{tabular}{lcccc}
\hline Source of variation & $\begin{array}{c}\text { Sum of } \\
\text { squares }\end{array}$ & $\begin{array}{c}\text { Variance } \\
\text { components }\end{array}$ & $\begin{array}{c}\text { Percentage } \\
\text { of variation }\end{array}$ & $\mathrm{p}$ \\
\hline Among populations & 40.98 & 0.23 & 12.28 & 0 \\
Within populations & 315.35 & 1.68 & 87.72 & 0 \\
\hline
\end{tabular}

sign-rank test for heterozygosity excess, using the two phase mutation model, resulted in the values 0.187 $(\mathrm{p}<0.01), 0.632(\mathrm{p}<0.01), 0.204(\mathrm{p}<0.001), 0.187$ $(\mathrm{p}<0.01)$ and $0.101(\mathrm{p}<0.01)$ for Ilhéus, Viçosa, Lavras, São Carlos and Guarapuava, respectively.

Although some pairwise estimates of relatedness $(r)$ were close to $25 \%$ (rarely above this value), low mean relatedness values between pairs of females of each population were observed [Ilhéus $(r=0.002 \pm 0.25)$, Lavras $(r=0.012 \pm 0.22)$, Viçosa $(r=0.014 \pm 0.3)$, São Carlos $(r=-0.0007 \pm 0.24)$ and Guarapuava $(r=-0.003 \pm 0.28)]$.

\section{Discussion}

Differences among populations were detected regarding the degree of variation in the microsatellite loci. As an example, TALB09 and TALB14 loci exhibited polymorphism in two and four populations, respectively. Allelic richness per locus was estimated for the five populations and private alleles were detected in at least one locus for each population analyzed. According to Kalinowski (2005), the number of alleles or allelic richness is a simple measure of genetic diversity that is highly dependent on sample size. Thus, the rarefaction method (Kalinowski, 2004) was employed to estimate allelic richness and the number of private alleles and minimize the sample size effect. The analysis revealed high level of allelic richness at most loci in each population (Table 2), including Guarapuava, which was the population with the smallest sample $(\mathrm{n}=12)$.
Expected intralocus heterozygosity did not differ substantially among populations, except for TALB01 (0.17 to 0.72). Comparatively, the smallest variation in He among populations (0.14 to 0.25 ) occurred at locus TALB09 and even the highly polymorphic locus TALB07 exhibited a low level of variation $(0.86$ to 0.93$)$. Thus, mean expected heterozygosity did not differ substantially among populations (range: 0.54 to 0.63 ) (Table 3 ), which was confirmed by a paired $t$-test using expected intralocus heterozygosity values for each population. Despite the similar heterozygosities, the number of private alleles at each locus differed (Table 2), suggesting inter-population differentiation.

The verification of Hardy-Weinberg equilibrium at each locus and T. albitarse population revealed that all loci, except TALB03, had at least a significant p-value $(<0.05)$. However following the Bonferroni correction, most deviations were found not to be significant. Deviations from Hardy-Weinberg equilibrium are generally associated with inbreeding, population structuring, the effects of natural selection, preferential mating, and/or the presence of null alleles (Templeton, 2011). Among these alternatives, the action of the natural selection seems unlikely, given that microsatellite markers are usually considered neutral and therefore free of the effects of this evolutionary mechanism. A high hit rate in the repeated genotyping (about 13\% of the female wasps of this study) associated to a positive amplification of 174 haploid males of T. albitarse genotyped for the same loci of this study (Bergamaschi et al., in press) indicated that null alleles may not be common in these loci. High frequencies of mating between relatives (endogamy) would certainly generate deviations in the Hardy-Weinberg equilibrium at all loci and not only in isolated cases, as observed in the present study.

$D_{\text {est }}$ values were higher than the corresponding $F_{s t}$ values and a positive association was found between the two indices (Table 4). Furthermore, AMOVA and the assignment test were also consistent with the $F_{s t}$ and $D_{e s t}$ values, thereby confirming that the populations analyzed are

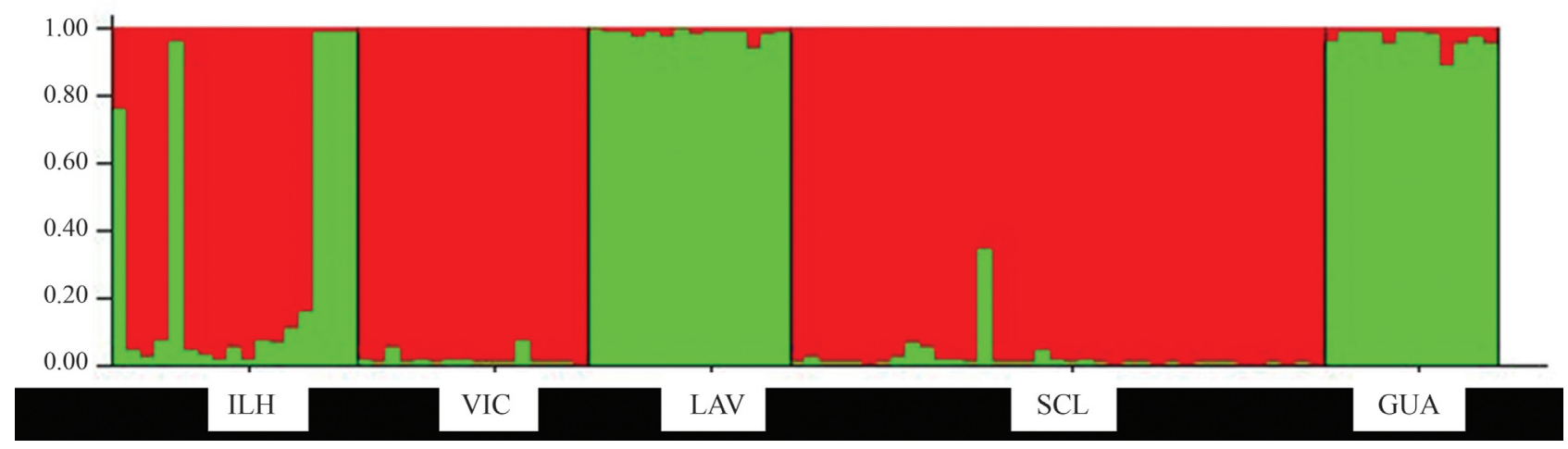

Figure 2 - Bayesian clustering plots of Trypoxylon albitarse populations genotyped using eight microsatellite loci when $K=2$ [each color represents one genetic cluster; each vertical column represents one individual and its chance of assignment to each of the two alternative genetic clusters (scale on the left)]. The site codes were described in Table 1. 


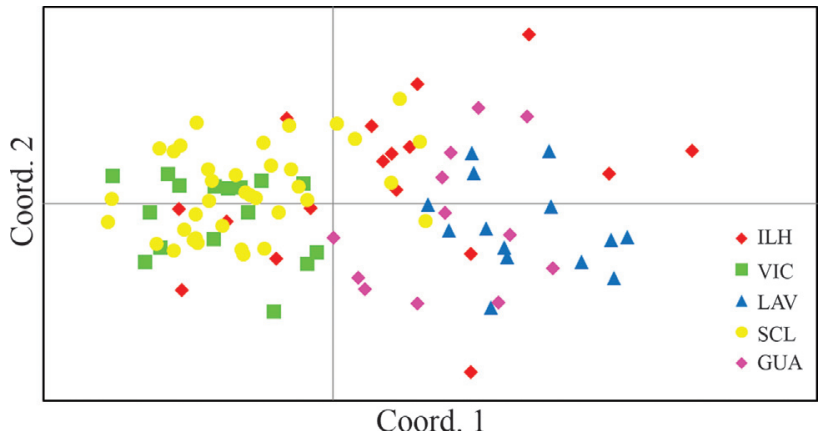

Figure 3 - Principal component analysis based on genetic distances obtained by genotyping at eight microsatellite loci for the females from five populations of Trypoxylon albitarse. Axes 1 and 2 explain 30.1\% and $18.4 \%$ of the genetic variation detected, respectively. The site codes were described in Table 1.

not genetically homogeneous, but show a moderate differentiation level according to the criterion of Wright (1978).

Bayesian analysis and PCA pointed to similar results. Two alternative genetic clusters were identified: one composed by the Viçosa and São Carlos populations and the second by the Lavras and Guarapuava populations. Individuals from Ilhéus were distributed between the two alternative groups. As expected, the Mantel test revealed no correlation between genetic and geographic distances.

The absence of genetic homogeneity, associated to the significant values of the inbreeding coefficient $\left(F_{i s}\right)$ among populations could be partially attributed to the presumed philopatry of Trypoxylon females. If an area is colonized by a small number of females, this results in a founder effect. If the growth of local populations occurs by the reproduction of the original nests, with the construction of satellite nests by daughters of the founding females, local populations would consist of few familial groups. Thus, despite the dispersal of males, some structuring would be possible due to the behavior of daughters nesting close to their native site. This hypothesis is in accordance with the possible recent demographic bottlenecks detected in all populations of $T$. albitarse studied. However, kinship analysis showed low genetic relatedness among females of the same population, suggesting that the dispersal ability of males may be sufficient to generate a low $r$ values among females of the same population. It is worthy of note that this result is not due to the low resolution power of the genetic markers employed, as $r$ values used to estimate the relatedness among individuals from the same nest were consistent with those expected for a predominantly monogamous genetic system (Bergamaschi et al., in press).

Little information is available on flight and dispersal capacity among species of Trypoxylon. Amarante (1991) reported a low recapture rate of adult specimens of $T$. albitarse during a behavioral study $(4.6 \%$ and $15.1 \%$ for females and males, respectively) and reported that specimens marked during nesting activity were observed up to 42 days after marking. Based on these findings, the author proposed that this species has good dispersal capacity. Studies involving other species of the genus also suggest that these wasps have a high emigration rate (Freeman, 1981; Molumby, 1997; Buschini and Bergamaschi, 2010, 2014; Buschini and Donatti, 2012). However, evidence regarding the degree of dispersal in T. albitarse is not coherent with the inter-population genetic differentiation observed in the present investigation and the one by Peruquetti (2003).

In conclusion, this study makes a significant contribution to knowledge on the population genetics of cabronid wasps, which has been rarely studied. Given the relevance of these wasps to the phylogeny of bees and the present findings of moderate inter-population heterogeneity, further studies involving the genotyping of other populations of $T$. albitarse in a more limited geographical scale, as well as phylogenetically related species, are needed to obtain more conclusive results about the effects of gene flow and female philopatry on the genetic differentiation among populations of Trypoxylon species.

\section{Acknowledgments}

The authors are grateful to Marco Antonio Costa (Universidade Estadual de Santa Cruz), Íris Stancíola (Universidade Federal de Viçosa), Lúcio Antonio de Oliveira Campos (Universidade Federal de Viçosa) and Maria Luísa Tunes Buschini (Universidade Estadual do Centro-Oeste) who generously provided support during the field sampling and allowed access to the study sites. This research was supported by Conselho Nacional de Desenvolvimento Científico e Tecnológico (CNPq 480706/2010).

\section{References}

Alexander BA (1992) An exploratory analysis of cladistics relationships within the superfamily Apoidea, with special reference to sphecid wasps (Hymenoptera). J Hymenopt Res $1: 25-61$

Almeida JC, Bergamaschi ACB, Sanchez A, Hatanaka T and Del Lama MA (2013) Isolation and characterization of microsatellite loci for the mud-dauber wasp Trypoxylon (Trypargilum) albitarse Fabricius, 1804 (Hymenoptera, Crabronidae). Eur J Entomol 110:541-543.

Amarante STP (1991) Biologia e Comportamento Reprodutivo de Trypoxylon (Trypargilum) albitarse F. (Hymenoptera, Sphecidae). Dissertation, Universidade de São Paulo.

Amarante STP (2002) A synonymic catalog of the Neotropical Crabronidae and Sphecidae (Hymenoptera, Apoidea). Arq Zool 37:1-139.

Archie JW (1985) Statistical analysis of heterozygosity data: Independent sample comparisons. Evolution 39:623-637.

Bergamaschi ACB, Almeida JCA, Campos LAO and Del Lama MA (in press) Sociogenetic structure in nests of the mud dauber wasp Trypoxylon (Trypargilum) albitarse Fabricius, 1804 (Hymenoptera, Crabronidae). Eur J Entomol.

Buschini MLT and Bergamaschi ACB (2010) Strongly femalebiased sex allocation in a trivoltine population of Trypo- 
xylon (Trypargilum) opacum Brèthes (Hymenoptera, Crabronidae). Acta Zool 91:433-439.

Buschini MLT and Bergamaschi ACB (2014) Sex ratio and parental investment in Trypoxylon (Trypargilum) agamemnon Richards (Hymenoptera, Crabronidae). Braz J Biol 74:231237.

Buschini MLT and Donatti AJ (2012) Nesting behavior of Trypoxylon (Trypargilum) agamemnom Richards (Hymenoptera, Crabronidae). Braz J Biol 72:353-362.

Debevec AH, Cardinal S and Danforth BN (2012) Identifying the sister group to the bees: A molecular phylogeny of Aculeata with an emphasis on the superfamily Apoidea. Zool Scripta 41:527-535.

Evanno G, Regnaut S and Goudet J (2005) Detecting the number of clusters of individuals using the software STRUCTURE: A simulation study. Mol Ecol 14:2611-2620.

Excoffier L, Smouse PE and Quattro JM (1992) Analysis of molecular variance inferred from metric distances among DNA haplotypes: Application to human mitochondrial DNA restriction data. Genetics 131:479-491.

Excoffier L, Laval G and Schneider S (2005) Arlequin v. 3.0: An integrated software package for population genetics data analysis. Evol Bioinform Online 1:47-50.

Fernandes-Salomão TM, Rocha RB, Campos LAO and Araújo EE (2005) The first internal transcribed spacer (ITS-1) from Melipona species (Hymenoptera, Apidae, Meliponini): Characterization and phylogenetic analysis. Insectes Soc 52:11-18.

Freeman B (1981) The dynamics in Trinidad of the Sphecid wasp Trypoxylon palliditarse: A thompsonian population? J Anim Ecol 50:563-572.

Goodnight KF and Queller DC (1999) Computer software for performing likelihood tests of pedigree relationships using genetic markers. Mol Ecol 8:1231-1234.

Jost L (2008) $\mathrm{G}_{\mathrm{ST}}$ and its relatives do not measure differentiation. Mol Ecol 17:4015-4026.

Kalinowski ST (2004) Counting alleles with rarefaction: Private alleles and hierarchical sampling designs. Conserv Genet 5:539-543.

Kalinowski ST (2005) HP-Rare: A computer program for performing rarefaction on measures of allelic diversity. Mol Ecol Notes 5:187-189.

Konovalov DA, Manning C and Henshaw MT (2004) KINGROUP: A program for pedigree relationship reconstruction and kin group assignments using genetic markers. Mol Ecol Notes 4:779-782.

Lohrmann V, Ohl M, Bleidorn C and Podsialowski L (2008) Phylogenie der "Sphecidae" (Hymenoptera, Apoidea) basierend auf molekularen daten. Mitt Dtsch Ges Allg Angew Entomol 16:99-102.

Lomholdt O (1982) On the origin of the bees (Hymenoptera, Apidae, Sphecidae). Entomol Scand 13:185-190.

Mantel NA (1967) The detection of disease clustering and a generalized regression approach. Cancer Res 27:209-220.

Melo GAR (1999) Phylogenetic relationships and classification of the major lineages of Apoidea (Hymenoptera), with emphasis on the crabronid wasps. Univ Kansas Sci Bull 14:155.
Melo GAR (2000) Comportamento social em vespas da família Sphecidae (Hymenoptera, Apoidea). In: Martins RP, Lewinsohn TM and Barbeiros MS (eds) Ecologia e Comportamento de Insetos. Série Oecologia Brasiliensis, Vol. VIII. PPGE-UFRJ, Rio de Janeiro, pp. 85-130.

Michener CD (2007) The Bees of the World. The John Hopkins University Press, Baltimore, $953 \mathrm{p}$.

Molumby A (1997) Why make daughters larger? Maternal sexallocation and sex-dependent selection for body size in a mass-provisioning wasp, Trypoxylon politum. Behav Ecol 8:279-287.

O’Neill KM (2001) Solitary Wasps: Natural History and Behavior. Cornell University Press, Ithaca, 406 p.

Peakall R and Smouse PE (2006) GenAlEx 6: Genetic analysis in Excel. Population genetic software for teaching and research. Mol Ecol Notes 6:288-295.

Peruquetti RC (2003) Aspectos da Biologia, Estrutura Populacional e Parentesco Intranidal em Vespas do Gênero Trypoxylon (Hymenoptera, Sphecidae). Thesis, Universidade Federal de São Carlos.

Piry S, Luikart G and Cornuet JM (1999) BOTTLENECK: A computer program for detecting recent reductions in the effective population size using allele frequency data. J Hered 90:502-503.

Prentice MA (1998) The Comparative Morphology and Phylogeny of Apoid Wasps (Hymenoptera, Apoidea). Thesis, University of California.

Pritchard JK, Stephens M and Donnelly P (2000) Inference of population structure using multilocus genotype data. Genetics 155:945-959.

Queller DC and Goodnight KF (1989) Estimating relatedness using genetic markers. Evolution 43:258-275.

Rice WR (1989) Analyzing tables of statistical tests. Evolution 43:223-225.

Santoni MM (2008) Biologia de Nidificação e Estrutura Sociogenética Intranidal em Espécies de Trypoxylon (Hymenoptera, Crabronidae). Dissertation, Universidade Federal de São Carlos.

Templeton AR (2011) Genética de Populações e Teoria Microevolutiva. Sociedade Brasileira de Genética, Ribeirão Preto, $705 \mathrm{p}$.

Walsh PS, Metzger DA and Higuchi R (1991) Chelex 100 as a medium for simple extraction of DNA for PCR-based typing from forensic material. Biotechniques 10:506-513.

Weir BS and Cockerham CC (1984) Estimating F-statistics for analysis of population structure. Evolution 38:1358-1370.

Wright S (1978) Evolution and the genetics of populations. Vol. 4. Variability Within and Among Natural Populations. University of Chicago Press, Chicago, 590 p.

\section{Internet Resources}

Pulawski WJ (2014) Catalog of Sphecidae sensu lato, http://research.calacademy.org/ent/catalog_sphecidae/16210 (September 9, 2014).

StatSoft, Inc (2004) STATISTICA (data analysis software system), version 7. www.statsoft.com (June 2015). 
Excoffier L, Laval G and Schneider S (2005) Arlequin software, http://cmpg.unibe.ch/software/arlequin3/ (September 9, 2014).

Goudet J (2001) FSTAT software, http://www2.unil.ch/popgen/softwares/fstat.htm (September 9, 2014).

Peakall R and Smouse PE (2006) GenAlEx software, http://biology-assets.anu.edu.au/GenAlEx/Welcome.html (September 9, 2014).
Kalinowski ST (2005) HP-Rare software, http://www.montana.edu/kalinowski/Software/HPRare.htm (September 9, 2014).

Pritchard JK, Stephens M and Donnelly P (2000) Structure software, http://pritchardlab.stanford.edu/structure.html (September 9, 2014).

Konovalov DA, Manning C and Henshaw MT (2004) Kingroup software, https://code.google.com/p/kingroup/ (September 9, 2014).

Associate Editor: Fabricio Rodrigues dos Santos

License information: This is an open-access article distributed under the terms of the Creative Commons Attribution License (type CC-BY), which permits unrestricted use, distribution and reproduction in any medium, provided the original article is properly cited. 